\title{
Refugee Representations: 1950s Non-Western/WWII Refugees in American Media with Smaller Circulation
}

\author{
Tova Anderson ${ }^{1 *}$
}

\begin{abstract}
This paper explores refugee representations in 1950s of non-western/World War II in American media, specifically "smaller circulation" media. I define local newspapers, academic studies and governmental documents. as "smaller circulation" because their readership was not as diverse or as large as mass media publications; they were read by people of a town (often small), those in federal governmental, legal positions, and academics. Therefore, this paper will discuss the results of these findings and suggest how the non-western/WWII refugees' condition was interpreted in these smaller circulation, how this contrasted a large contemporary and importantly local refugee movement and finally, a suggestion of the implications. My findings suggest that during the 1950s, smaller circulation American print publications discussed non-western/WWII refugees in a political and pragmatic manner, and linked refugees to a particular cause (such as Communism) or nationality, and on the whole did not prioritize them: ironically, this is even in light of the World Refugee Year from 1959-1960, discussed by Gatrell. Publications generally depicted refugees without pictures or art or statistics, but instead depended on written descriptions.
\end{abstract}

\section{Keywords}

World War II - Refugees - News Media

${ }^{1}$ Department of Art Education and Art History, University of North Texas

${ }^{*}$ Faculty Mentor: Dr. Jennifer Way

\section{Introduction \\ 1 Local Newspapers \\ 2 Conclusion}

Contents

Author Biography

\section{Introduction}

At the beginning of this research project, my focus was on refugee representations in 1950s of non-western/World War II in American media. However, upon seeing that academic attention has already been given to mass media representations (for example, the New York Times, Washington, DC papers, Time, Newsweek, Life, etc.), of non-western/WWII refugees in the 1950s America, I discovered and turned to lesser known pieces of literature: local newspapers, academic studies, and governmental documents (court cases, Department of State Bulletins, Presidential speeches, etc.). I define local newspapers, academic studies and governmental documents. as "smaller circulation" because their readership was not as diverse or as large as mass media publications; they were read by people of a town (often small), those in federal governmental, legal positions, and academics. Therefore, this paper will discuss the results of these findings and suggest how the non-western/WWII refugees' condition was interpreted in these smaller circulation, how this contrasted a large contemporary and importantly local refugee movement and finally, a suggestion of the implications. To begin with general statements about these refugees, as noted by Liisa H. Malkki in her review of refugee literature, ${ }^{1}$ these 1950 s non-Western/nonWWII refugees were among the first refugees to be seen as a people group to be aided internationally because WWII was the beginning of the modern conception of a refugee. ${ }^{2}$

Peter Gatrell's book, Free World? The Campaign to Save the World's Refugees, 1956-1963 also contextualizes the refugee representation of the era, and will be used later in this paper to discuss a large local refugee movement and its media. ${ }^{3}$ For general refugee information pertinent to this paper, Gatrell relays that the US government was the "most powerful institutional influence on migration" during the midcentury, particularly with the US Escapee Program (USEP) that helped refugees fleeing from Communism. ${ }^{4}$ The US

\footnotetext{
${ }^{1}$ Malkki, Liisa H. "Refugees and Exile: From "Refugee Studies" to the National Order of Things." Annual Review of Anthropology, Vol. 24, 1995 , pp. 495-523.

${ }^{2}$ Malkki, 497-8.

${ }^{3}$ Gatrell, Peter. Free World? The Campaign to Save the World's Refugees, 1956-1963. Cambridge: 2011.

${ }^{4}$ Gatrell, 20-1.
} 
appeared to allow more refugees of different nationalities (with quotas based on these nationalities) than other Western nations. $^{5}$

My findings suggest that during the 1950s, smaller circulation American print publications discussed non-western/WWII refugees in a political and pragmatic manner, and linked refugees to a particular cause (such as Communism) or nationality, and on the whole did not prioritize them: ironically, this is even in light of the World Refugee Year from 1959-1960, discussed by Gatrell (and to be explained later). Publications generally depicted refugees without pictures or art or statistics, but instead depended on written descriptions.

\section{Local Newspapers}

Regarding the local newspapers, they addressed refugees in a political manner by generally stating: here is what is happening to this group of refugees along with a description of what the country or cause is doing to make these refugees flee. Refugees were never discussed as a part of a "refugee problem", as they were not addressed as an international dilemma till the mid-late 1940s. ${ }^{6}$ These non-Western/WWII refugees as seen in smaller circulation publications, I define as peoples from Asian, African, or Eastern European countries; the most discussed refugees were Koreans at the beginning of the decade, and Vietnamese, Laotians, Hungarians at the end. They primarily relayed how the United States, not other countries, aided or received these refugee groups.

Because these local newspapers emphasized who was helping the refugees, their stories for the most part came across as pragmatic, or delineating the nations aiding refugees, the refugees aiding themselves, and occasionally, the reader aiding the refugees (food can drives, etc.) Though refugees were described at times with emotion-provoking language, the articles in these newspapers did not often leave the reader with pitiful and helpless images, except to blame an offending nation or cause. Instead, the United States and occasionally the UN were listed as taking in refugees or aiding them, but the details of how they went about it were not listed. These newspaper articles only used such details when discussing smaller events. For example, in a Montanan newspaper in 1957, American and Norwegian students in a private American organization attempted to help Hungarian refugees across the border. ${ }^{7}$ Refugees, though victims, were generally shown as trying to escape or work against the country or cause of their distress. Finally, advertisements in the newspapers occasionally discuss what a local organization or religious group was collecting for refugees and where the donations could be left. Other than the sympathetic descriptions and chastising politicians for not supporting refugees, local newspapers portrayed how refugees' situations had been or would be changed without prodding their plausibility. Malkki suggests that refugee

\footnotetext{
${ }^{5}$ Gatrell, 44.

${ }^{6}$ Malkki, 497-8.

${ }^{7}$ Butte Montana Standard: Sunday, January 13, 1957, Butte Montana.
}

camps in Europe after the WWII "depended heavily on improvisation", and thus weren't questioned because of the state of emergency and novelty of the problem. ${ }^{8}$ Perhaps the US worked from improvisation and so did not believe there were time constraints.

What was not reported in these local papers were the American governmental decisions and logistics on how to help refugees. For example, in 1953-5, none of the newspapers that I found mentioned the Refugee Relief Act of 1953 that was passed to aid more than WWII refugees, and then was amended in 1954 and changed by Eisenhower in 1955. Neither this Act, its amendment and changes, or the plethora of related court cases were queried. The academic studies on the other hand, discussed how refugees in a very particular circumstance (such and such American city with refugees of this nationality/ethnicity, etc.) were or were not being helped with statistics in a sociological manner. None of these however categorized themselves as "refugee studies" because as Malkki argues, "refugee studies" did not appear in a systematic way till the 1970s and 80s", and these "studies", as stated above, were very narrow in focus, often collecting information for a particular charity organization. ${ }^{9}$ Thus, academic studies were as pragmatic as government documents and newspapers.

How, besides a political and pragmatic way, else were refugees represented in local or governmental or academic publications? Though there were a few ethnic and religious causes cited in academic studies, non-Western/WWII refugees were generally presented as victims of Communist rule, particularly in the local newspapers. Federal court cases and Department of State Bulletins did prioritize refugees from Communist countries, while academic studies hardly favored or negated this promoted causation. Newspaper articles were a completely different story. For example, one incident of Vietnamese and Laotian refugees was greatly talked about amongst several newspapers in 1959. With the Northern Vietnamese, they were said to have fled to Thailand and then decided to return. With the Laotians, the UN was debating if it had been the North Vietnamese to have attacked Laotians, and one newspaper notes that the US believed it was the North Vietnamese's fault ${ }^{10}$ and another newspaper asserts this by calling its article "Reds Stage Laos Terror War". ${ }^{11}$ Concerning refugees that had entered the United States, another newspaper relays that refugees received emotion-appealing mail from their Soviet homelands to try to get them to return. ${ }^{12}$ What I found the most surprising is that despite the "Red Scare", only one incident of this scare amongst these smaller circulation sources was connected to refugees: Vice President Nixon calmed people's fears of Communists being among the Hungarian refugees arriving in the US. ${ }^{13}$

With mainly written representations, refugees were hardly

\footnotetext{
${ }^{8}$ Malkki, 499.

${ }^{9}$ Malkki, 507.

${ }^{10}$ Findlay Republican Courier, Friday, September 18, 1959, Findlay, Ohio.

${ }^{11}$ Corsicana Daily Sun, Tuesday, August 25, 1959, Corsicana, Texas.

${ }^{12}$ El Paso Herald Post, Monday, June 4, 1956, El Paso, Texas.

${ }^{13}$ Lowell Sun, Sunday, January 13, 1957, Lowell Massachusetts.
} 
prioritized in smaller circulation publications. First, there is the matter of quantity; many of databases I searched gave few or unrelated sources (that were not mass media). Even among the secondary sources (academic), finding material was difficult. While searching in Newspaper Archives, where I found most of my newspaper sources, I had great difficulty finding the reference to refugees: the articles were almost always short and positioned off to one side. I found only two examples of refugees receiving more than an aside article, neither of which were on the front page. One cartoon relates to Soviets writing to American refugees to return home. ${ }^{14}$ In another, the headline included the word "refugee." 15 However, these "refugees", five Venezuelan men, were fleeing to Mexico for admitting to trying to attack the Venezuelan President and government. With other printed media, I attempted to utilize secondary sources, since primary sources were not giving pictures, or other forms of media: only one secondary (academic) article included a picture, two movie posters; and two US government propaganda posters ${ }^{16}$ and one other mentioned a painting on refugees ${ }^{17}$ that I could not locate. By these local newspapers not centralizing refugee stories or representing them without pictures, their stories can seem sterile. By not even reporting one's government's legislation or academic studies to aid this legislation on refugees' behalf, the US' aid appears mysterious. Finally, no secondary source material except Gatrell studies these refugees' representation.

Nothing in the local or smaller circulation American publications that I found suggested that the US would be among the top two world financial supporters among the ninety-seven participating countries for the World Refugee Year (WRY), as Gatrell delineates. ${ }^{18}$ To give some background, WRY was spurred from the needs of the Hungarian refugee crisis (from the Hungarian Revolt of 1956), ${ }^{19}$ and emerged from the Conservative Party in Britain. ${ }^{20}$ Their goal was to form a grass-roots movement that "provided important opportunities for institutional and personal networking at a local, national, and international level" 21 that was not bound by political systems or agendas: in other words, though Soviet countries did not participate, the organization did not focus on the Cold War. ${ }^{22}$ Gatrell writes that through aligning the UN, NGOs, many world governments, the World Council of Churches, the Catholic Church, and private individuals and organizations, WRY hoped to not only raise funds, but also demonstrate "community solidarity", ${ }^{23}$ especially on behalf of refugees

\footnotetext{
${ }^{14}$ El Paso Herald Post, June 4, 1956.

${ }^{15}$ Odessa American, December 8, 1959.

${ }^{16}$ Carruthers, Susan L. 2005. "Between Camps: Eastern Bloc "Escapees" and Cold War Borderlands" American Quarterly 57 (3): 911-942.

${ }^{17}$ Eldredge, C. (2006). "Irving Norman, Redwoods, and 'Refugees'." American Art, 20(2), 26-28.

${ }^{18}$ Gatrell, 206.

${ }^{19}$ Gatrell, 47.

${ }^{20}$ Gatrell, 82 .

${ }^{21}$ Gatrell 138 .

${ }^{22}$ Gatrell, 137

${ }^{23}$ Gatrell, 138 .
}

from the Far and Middle East. ${ }^{24}$ As stated before, it lasted from 1959-1960. Thus, it was one of the first grass-root movements of the 20th Century.

Importantly, for this discussion, there was supposed to have been a great deal of media on WRY: "numerous photos and films and graphic art". ${ }^{25}$ There were even WRY stamps published by several countries, including the US. ${ }^{26}$ The first question that would emerge from comparing the WRY paraphernalia to American local or smaller circulation publication is, why there is no overlap? If WRY was a grass-roots movement, where is the local media and advertisements for it? Unfortunately, though Gatrell speaks of the US' financial contributions, he displays little of American WRY media or if media prompted most of the giving, or if it was truly personal testimonies or through other organizations' media (United Nations, non-governmental organizations, etc.)

\section{Conclusion}

To close, smaller circulation print publications in 1950s America portrayed non-Western/WWII refugees as needing help from Communism or other forces and this help taking a political, positive (pro-refugee), and pragmatic form, but not seen as pressing issues because of a lack of quantity, length, photographic media or positioning in these smaller circulation publications. For further research, since there is a scarcity of secondary source material regarding representations of these refugees in any kind of media, a comprehensive and comparative study of these refugees in all media (mass and smaller circulation).

\section{Author Biography}

Tova Anderson hails from Highland Village, Texas. She will be graduating with honors this December (2017) with Integrative Studies in Art History, English, French, and a minor in Music.Tova has been in the Honors College since her freshman year at UNT. In her sophomore year, she presented a research proposal at Scholar's Day. Tova was also awarded an Undergraduate Research Fellowship in 2016 and presented her findings at the 2017 Scholar's Day. She plans to pursue a Masters in English in 2018 and will seek a career in elementary through high school education or editorial work for non-profits.

\footnotetext{
${ }^{24}$ Gatrell, 49 .

${ }^{25}$ Gatrell, 168 .

${ }^{26}$ Gatrell, 185 .
} 


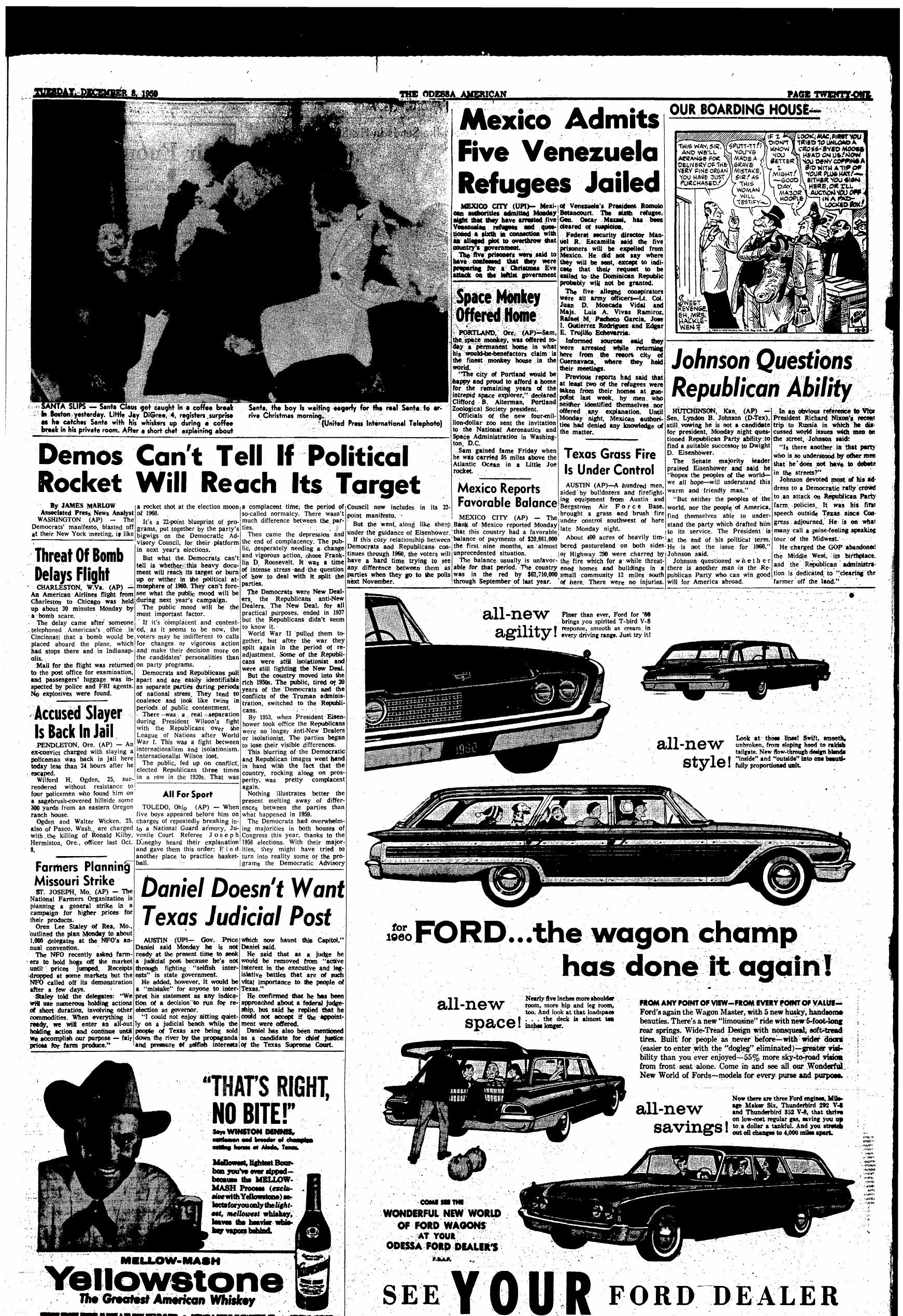

